\title{
TAKING STOCK OF NETWORKS AND ORGANIZATIONS: A MULTILEVEL PERSPECTIVE
}

\author{
DANIEL J. BRASS \\ University of Kentucky \\ JOSEPH GALASKIEWICZ \\ University of Arizona \\ HENRICH R. GREVE \\ Norwegian School of Management BI \\ WENPIN TSAI \\ Pennsylvania State University
}

\begin{abstract}
The central argument of network research is that actors are embedded in networks of interconnected social relationships that offer opportunities for and constraints on behavior. We review research on the antecedents and consequences of networks at the interpersonal, interunit, and interorganizational levels of analysis, evaluate recent theoretical and empirical trends, and give directions for future research, highlighting the importance of investigating cross-level network phenomena.
\end{abstract}

A quarter century of social network research in management journals has resulted in the accumulation of many findings in recent years (see, for example, Borgatti and Foster [2003] for a recent review). Network studies have appeared regularly in management journals, contributing to the investigation of a wide range of organizational topics across different levels of analysis (for a discussion of the concepts, techniques and measures in network analysis, see, for example, Wasserman and Faust [1994]). The purpose of this article is to evaluate organizational network research. Where have we been? What do we know? Where are we going? To that end, we take stock of the results of organizational network research at the interpersonal, interunit, and interorganizational levels of analysis, focusing on the antecedents and consequences of networks at each level. We hope to generate future research directions by assessing where network scholarship currently is.

Network research embraces a distinctive perspective that focuses on relations among actors, whether they are individuals, work units, or organizations. According to the network perspective, actors are embedded within networks of intercon-

The order of authorship is alphabetical, reflecting equal contributions from the four authors. We thank all reviewers and authors who helped make this special research forum possible, and above all we thank Tom Lee for his strong support throughout this process. nected relationships that provide opportunities for and constraints on behavior. This perspective differs from traditional perspectives in organizational studies that examine individual actors in isolation. The difference is the focus on relations rather than attributes, on structured patterns of interaction rather than isolated individual actors. It is the intersection of relationships that defines an individual's centrality in a group, a group's role in an organization (White, Boorman, \& Breiger, 1976), or an organization's niche in a market (McPherson, 1983).

We define a network as a set of nodes and the set of ties representing some relationship, or lack of relationship, between the nodes. We refer to the nodes as actors (individuals, work units, or organizations). The particular content of the relationships represented by the ties is limited only by a researcher's imagination. Typically studied are strategic alliances and collaborations, flows of information (communication), affect (friendship), goods and services (work flow), and influence (advice), and overlapping group memberships such as boards of directors. We consider ties that are maintained over time, thus establishing a relatively stable pattern of network interrelationships.

Using this network perspective, organizational researchers have been able to explain variance in such traditional organizational outcomes as individual satisfaction, performance, and job exit; group structure and performance; and organiza- 
tional innovation and survival. Likewise, research has focused on the antecedents of networks. We organize our review around antecedents and consequences of networks by levels of analysis. We begin with the interpersonal level of analysis (individual people as actors), then consider interunit networks (groups as actors), and follow with the interorganizational level of analysis (organizations as actors). In each case, we consider the antecedents and consequences, noting what researchers know, what they don't, and future directions for research.

\section{INTERPERSONAL NETWORKS}

\section{Antecedents of Interpersonal Networks}

Actor similarity. Similar people tend to interact with each other. Similarity is thought to ease communication, increase the predictability of behavior, and foster trust and reciprocity. A good deal of research has supported this proposition, and it is a basic assumption in many theories (Blau, 1977; Davis, 1966; Granovetter, 1973; Homans, 1950). Similarity has been operationally defined on such dimensions as age, sex, education, prestige, social class, tenure, and occupation (Carley, 1991; Ibarra, 1993; Laumann, 1966; Lazerfield \& Merton, 1954; McPherson \& Smith-Lovin, 1987; McPherson, Smith-Lovin, \& Cook, 2001). For example, Brass (1985a) and Ibarra (1992) found evidence for homophily (interaction with similar others) based on gender in organizations, observing two largely segregated networks, one predominately men, the other women, in different settings. Mehra, Kilduff, and Brass (1998) found that racial minorities were clustered on the periphery of networks. Also, research on relational and organizational demography (Tsui \& O'Reilly, 1989; Wagner, Pfeffer, \& O'Reilly, 1984) has been based on the homophily principle; ease of communication and social integration have been the assumed mediating variables in these studies.

Although there is extensive research on homophily in networks, it is often unclear which dimension of "similarity" will be manifest in a given organizational context. It is important to note that similarity is a relational concept; an individual can only be similar with respect to another individual, and in relation to dissimilar others. That is, interaction is influenced by the degree to which an individual is similar to other individuals relative to how similar he or she is to everyone else (Mehra et al., 1998). Culture, selection, and socialization processes and reward systems may cause an organization to exhibit a modal similarity pattern. Kanter
(1977) referred to this process as "homosocial reproduction." Thus, an individual's similarity in relation to the modal attributes of an organization (or a group) may determine the extent to which he or she is central or integrated in the interpersonal network.

Personality. Many radical structuralists would argue that personality is a result of network position. However, research indicates that personality can affect social network patterns. Mehra, Kilduff, and Brass (2001) found that people in the center of the networks they studied scored high on self-monitoring, a stable personality characteristic that indicates the extent to which people monitor environmental cues and modify their behavior to meet external expectations. In a study that appears in this issue, Klein, Lim, Saltz, and Mayer (2004) found that several personality characteristics predicted centrality in advice, friendship, and adversarial networks within teams. In addition, personality has been show to be related to accurate perceptions of networks (Casciaro, 1998).

Proximity and organizational structure. The focus on actor similarity and personality implies that interactions within organizations are voluntary. However, organizational structure shapes networks in organizations. Labor is divided, positions are formally differentiated both horizontally (by work flow and task design) and vertically (by hierarchy), and means for coordinating among differentiated positions are specified. Formally differentiated positions locate individuals and groups in physical space and at particular points in an organizations's work flow and hierarchy of authority, thereby restricting their opportunity to interact with some others and facilitating interaction with still others. Because it would be difficult for a superior and subordinate directly linked by a formal hierarchy to avoid interacting, it would not be surprising for an "informal" social network to shadow the formal hierarchy of authority. For example, research has shown that social networks differ in organic and mechanistic organizations (Tichy \& Fombrun, 1979; Shrader, Lincoln, \& Hoffman, 1989). In general these results suggest more unrestricted, flexible interaction in organic organizations than in mechanistic organizations. In addition, Lincoln and Miller (1979) found that rank was related to centrality in task and friendship networks. Although sex and race were related to friendship network centrality, Lincoln and Miller's results emphasize the extent to which organizational structure constrains friendship as well as instrumental ties.

Networks are influenced by the work flow requirements of organizations as well. Longitudinal 
studies have found that communication patterns change when organizations adopt new technologies (Burkhardt \& Brass, 1990; Papa, 1990). Recent changes in communication technology, such as electronic mail, have generated increased interest in technology's effects on communication networks (Fulk \& Steinfield. 1990).

To the extent that formal structures situate actors in physical and temporal space, they exert an additional influence on network building. For example, actors scheduled to work at the same time are more likely to communicate. Festinger, Schachter, and Back (1950) established the link between physical proximity, interaction, and friendship. Their research suggests that proximity is more important than actor similarity or personality. More recently, Borgatti and Cross (2003) found that physical proximity mediated the relationship between knowing what other actors know, valuing it, and timely access to information seeking. Although the use of telephones and electronic mail may moderate the relationship between proximity and interaction, proximate ties are easier to maintain and more likely to be strong, stable links (Monge \& Eisenberg, 1987). It is also likely that proximity facilitates initial contact, whereas e-mail may help maintain relationships once they have formed.

Environmental factors. Mergers and acquisitions are environmental jolts that can substantially change network patterns within an organization. Danowski and Edison-Swift (1985) found dramatic changes in electronic mail usage following a merger. However, these changes were temporary, as employees reverted to premerger patterns after a short time. Similarly, environmental events such as downsizing significantly affect intraorganizational networks (Shah, 2000).

There is evidence that national culture influences social network patterns within organizations. For example, French employees prefer weak links at work, whereas Japanese workers tend to form strong, multiplex ties (Monge \& Eisenberg, 1987). Given the Japanese group orientation to decision making, as opposed to the individualistic emphasis in the United States as a whole, we might expect density and interconnectedness to be greater in Japanese companies. Future research may fruitfully focus on the effects of both national and organizational culture on interpersonal networks.

\section{Consequences of Interpersonal Networks}

Established patterns of interaction become institutionalized and take on the qualities of socially shared, structural facts. Network patterns emerge, become routine, and both constrain and facilitate behavior. Attitudes and behaviors change as a result of networks. We now turn our attention to the consequences of interpersonal networks.

Attitude similarity. Theory and research have also noted that, just as similar actors are prone to interact, those who interact become more similar. People are not born with their attitudes, nor do they develop them in isolation; attitude formation and change occur primarily through social interaction (Erickson, 1988). As people seek to make sense of reality, they compare their own perceptions with those of others.

Research on attitude similarity in organizations has focused on debate over whether attitudes are formed through direct interaction or through structural equivalence. Structural equivalence refers to the extent to which actors occupy similar positions or roles in a network. According to Burt (1982), actors compare their own attitudes and behaviors with those of others occupying similar roles, rather than being influenced by direct communications from others in dissimilar roles. Thus, we might expect managers to have attitudes similar to other managers' attitudes, rather than to subordinates'. Studies by Walker (1985), Galaskiewicz and Burt (1991), and Burkhardt (1994) have supported the structural equivalence perspective, but studies by Kilduff (1990), Rice and Aydin, (1991), Pastor, Meindl, and Mayo (2002), and Umphress, Labianca, Brass, Kass, and Scholten (2003) have found support for the direct contact perspective. Although interest in the debate has waned, it is clear that social networks can affect attitudes.

Job satisfaction. Perhaps the most frequently researched attitude in organizational studies is job satisfaction. Early laboratory studies (see Shaw [1964] for a review) indicated that central actors were more satisfied than peripheral actors in small groups, yet field research results have been mixed. In one of the few studies of job satisfaction conducted in the field, Roberts and O'Reilly (1979) found that relative isolates (people with zero or one link) in an organization's communication network were less satisfied than participants (those with two or more links). Morrison (2002) found that organizational commitment (a construct related to organizational satisfaction) was associated with the closeness of friendship ties for organizational newcomers. However, Brass (1981) found no relationship between centrality in the work flows of work groups or departments and employee satisfaction. Centrality within an entire organization's work flow had a negative relationship to satisfaction, a finding that may reflect the routineness of jobs associated with the core technology of an organization.

These mixed results suggest that interaction is 
not always positive. Since Durkheim (1997/1951) argued that social integration promotes mental health, there has been a long history of equating social interaction with social support (Wellman, 1992). Yet we have all experienced the obnoxious coworker, the demanding boss, or the uncooperative subordinate. When possible, we tend to avoid interaction with these people, thereby producing a positive correlation between interaction, friendship, and job satisfaction. However, physical proximity and organizational structure constrain the voluntary nature of social interaction in organizations. The possibility that such "required" interaction may involve negative outcomes suggests the need for further research on the negative side of social interaction (Labianca \& Brass, 2004). A nonlinear, inverted U-shaped relationship between network centrality and job satisfaction may eventually be found. Isolation is probably negatively related to satisfaction, while a high degree of centrality may lead to interaction with unpleasant others, conflicting expectations, and stress.

Power. A network perspective on power and influence has been the topic of much research. The finding that central network positions are associated with power has been reported for small, laboratory work groups (Shaw, 1964) as well as for interpersonal networks in organizations (Brass, 1984, 1985a; Brass \& Burkhardt, 1993; Burkhardt \& Brass, 1990; Krackhardt, 1990). Theoretically, actors in central network positions have greater access to, and potential control over, relevant resources, such as information in a communication network. Actors who are able to control relevant resources and thereby increase others' dependence on themselves acquire power. In addition, actors must also decrease their dependence on others. They must have access to relevant resources that are not controlled or mediated by others.

Simple measures of network size have been associated with power (Brass \& Burkhardt, 1992, 1993; Burkhardt \& Brass, 1990). Blau and Alba (1982) found that ties linking different work groups increased actors' power. Brass (1984) found that centrality in larger departments was a better predictor of power than centrality in smaller subgroups. Both of those studies (Blau \& Alba, 1982; Brass, 1984) and Ibarra (1992) showed that group membership was related to individual power. In addition, Krackhardt (1990) found that others viewed people who had more accurate cognitive maps of the social network in an organization as more influential. That is, power was related to the degree to which an individual's perception of the interaction network matched the "actual" social network. In a case analysis, Krackhardt (1992) dem- onstrated how a lack of knowledge of the social network in a firm prevented a union from successfully organizing employees.

One's power also depends upon to whom one is linked. Brass (1984) found that ties beyond work group and work flow requirements were related to influence. In particular, closeness to the dominant coalition in an organization was strongly related to power and promotions. Men were more closely linked to this dominant coalition (composed of four men) and were perceived as more influential than women (Brass, 1985a). Assuming that men dominate power positions in most organizations, women may be forced to forgo any preference for homophily in order to build connections with dominant coalitions. Thus, organizational context constrains preferences for homophily, especially for women and minorities (Ibarra, 1993). In suggesting that network position represented potential power (that is, access to and control of resources), and that behavioral tactics represented the strategic use of resources, Brass and Burkhardt (1993) concluded that behavioral tactics decreased in importance as network position increased in centrality.

Getting a job. Networks are valuable in job search and recruitment, particularly for high-paying, high-responsibility jobs such as managerial positions. Previous studies have shown that people find jobs more effectively through weak ties (acquaintances) than through strong ties (friends) or formal listings (e.g., Granovetter, 1982). An actor's acquaintances are less likely to be linked to one another than are an actor's close friends and are thus more likely to provide nonredundant information. Thus, individuals have greater access to more and different job opportunities when relying on weak ties. Later findings have modified and emphasized this notion, showing that weak ties used in finding jobs were associated with higher occupational achievement when they connected the job seekers to those of higher occupational status (e.g., de Graaf \& Flap, 1988, Lin, Ensel, \& Vaughn, 1981; Marsden \& Hurlbert, 1988; Wegener, 1991). Thus, the effectiveness of weak ties rests in the diversity and nonredundancy of the information they provide. In studying job markets in the People's Republic of China, Bian (1997) found that people's strong ties were more effective in getting them good jobs. It seems that when the costs of providing valued information are high, strong rather than weak ties are needed.

Organizations have recently established formal recruiting networks based on employee referrals. Network referrals can provide richer pools of applicants, better matches between referred applicants and job requirements, and social support 
from referees once referred applicants are hired (Fernandez, Castilla, \& Moore, 2000). In a related study, Seidel, Polzer, and Stewart (2000) found that recruits' social ties to an organization increased salary negotiation outcomes. Two studies of the socialization of new employees (Jablin \& Krone, 1987; Sherman, Smith, \& Mansfield, 1986) have indicated that network involvement is a key process in their assimilation.

Performance. The network perspective on performance invites one to analyze patterns of relationships rather than view individuals' performance in isolation. As is the case with interdependent tasks in organizations, relationships with others affect performance, especially if those relationships involve the ability to acquire necessary information and expertise.

Recent studies have found a link between centrality and performance in complex jobs; these include Mehra and colleagues (2001) and a study, reported in this issue, by Cross and Cummings (2004). Papa (1990) found that performance following a technological change was related to interaction frequency, network size, and network diversity (number of ties to other departments and hierarchical levels). This conclusion is consistent with small-group laboratory network studies (see Shaw [1964] for a review) that indicated that task complexity was an important moderator of the networkperformance relationship (see also Brass, 1981, 1985b; Roberts \& O’Reilly, 1979). That is, performance is better when communication structure matches the information-processing requirements of a task. This logic suggests it is likely that network connections are most useful when jobs require creativity (Brass, 1995; Perry-Smith \& Shalley, 2003). However, Sparrowe, Liden, Wayne, and Kraimer (2001) found that supervisors' ratings of performance were positively related to centrality across a variety of jobs. Also, research has shown that citizenship behavior is positively related to network centrality (Settoon \& Mossholder, 2002).

Getting ahead. Getting ahead in organizations has often been said to be a matter of "who you know, not what you know." This statement emphasizes the importance of "social capital" as compared to "human capital," attributes such as education, intelligence, and attractiveness (Burt, 2000). Most managers' careers are contingent on what they can effectively accomplish in connection with others. Thus, the social network framework provides a useful perspective for focusing on the importance of social relationships for careers. To the extent that acquiring power and influence is related to upward mobility and success, much of the previous discussion of networks and power applies. For example,
Brass (1984, 1985a) found that network indicators of power also related to promotions of nonsupervisory employees over a three-year period.

Burt (1992) noted that network relations can be costly to maintain, suggesting that selectivity in choosing relationships is important. Strong, close relationships require more time than weak (acquaintance) relationships, raising the question of whether managers should develop weak relationships with many coworkers or strong personal relationships with a few coworkers or with a mentor. Burt (1992) argued that the size of one's network and strength of one's ties are not as important as the diversity of one's contacts: The key is having a network rich in structural holes. A structural hole is defined as the absence of a link between two contacts who are both linked to an actor. Not only does the actor gain nonredundant information from the contacts (Granovetter's weak tie argument), but also, the actor is in a position to control the information flow between the two (that is, to broker the relationship), or to play the two off against each other. Using the criterion of early promotions, Burt (1992) found the structural hole strategy to be effective for established, male managers and that bridging structural holes was the most valuable for managers with few peers (Burt, 1997). Also supporting the structural hole argument, Seibert, Kraimer, and Liden (2001) found that weak ties and structural holes in a career advice network were positively related to social resources, which in turn were related to salary, promotions over careers, and career satisfaction. Also, Podolny and Baron, (1997) found that having a large, sparse informal network with many structural holes enhanced career mobility.

However, sparse, nonredundant networks do not always produce the best outcomes for women and newly hired managers (Burt, 1992). Because these "players" may face barriers to entry into established networks, a strong connection to powerful, well-connected mentors may be more beneficial. The strong tie strategy allows an employee to be central by virtue of a few direct links to others who have many direct links. However, reliance on indirect links creates a dependency on the highly connected other (see Higgins \& Kram, 2001) to mediate the flow of resources. Thus, a strong, trusting tie to a highly connected other is potentially valuable, but risky.

There is considerable empirical support for this thesis. Kilduff and Krackhardt (1994) found that the perception of a friendship link to a prominent person in an organization tended to boost an individual's performance reputation. Likewise, Brass (1984, 1985a) found that links to supervisors and 
dominant coalitions were related to promotions for both men and women. Boxman, de Graaf, and Flap (1991) found no differences in predictors between men and women in their study of 1,359 Dutch managers. External work contacts and memberships were related to income attainment and position level even when human capital (education and experience) were controlled for, and the return on human capital decreased as social capital increased.

Turnover. In a study of fast-food restaurants, Krackhardt and Porter (1986) found that job exits ("turnover") did not occur randomly, but occurred in structurally equivalent clusters in the restaurants' communication networks. Krackhardt and Porter (1985) also examined the effects of turnover on the attitudes of those who remained in organizations and found that the closer an employee was to those who left, the more satisfied and committed the remaining employee became. The authors argued that remaining employees cognitively justified their decision to stay by increasing their satisfaction and commitment.

Research on relational and organizational demography (Tsui \& O’Reilly, 1989; Wagner et al., 1984) has shown that similarity in age and tenure among group members is related to turnover. Combining this observation with our previous review of homophily results, we can predict that similarity leads to increased communication, which, in turn, is negatively related to turnover. McPherson, Popielarz, and Drobnic (1992) supported this prediction. In voluntary organizations, they found, network ties within a group were associated with reduced turnover, while ties outside the group increased turnover. This finding has been reproduced in interorganizational networks (Rao, Davis, \& Ward, 2000).

Leadership. Although little empirical work has been done on leadership and social networks, there are several reasons to believe that social networks may affect leadership effectiveness. Small-group laboratory studies in the 1950s (see Shaw [1964] for a review) showed that central actors in centralized network structures were overwhelmingly chosen as leaders of the groups. Leadership is essentially an influence process that can be described as a network phenomenon (Brass \& Krackhardt, 1999; Sparrowe \& Liden, 1997). The extensive work on leader-member exchange (LMX; Graen \& Scandura, 1987; Sparrowe \& Liden, 1997) has shown the importance of relationships between supervisors and subordinates. Mehra, Dixon, Brass, and Robertson (2003) found that differences in leaders' social networks were related to differences in the economic performance of their units as well as to their personal reputations as leaders.
Unethical behavior. Networks can serve socially negative as well as positive ends (Brass, Butterfield, \& Skaggs, 1998; Gargiulo \& Benassi, 1999). For example, in a critique of economics, Granovetter (1985) outlined the effects of social structure on trust and malfeasance. In a rare empirical study of unethical behavior, Baker and Faulkner (1993) studied price-fixing conspiracies (illegal networks) in the heavy electrical equipment industry. They found that convictions, sentences, and fines were related to personal centrality, decentralized network structure, and a middle management level. Raab and Milward (2003) described the Al Qaeda terrorist network as a network of project teams that operated independently from each other and a tightly knit core. The ultimate success of these conspiratorial networks is to stay secret but still ensure enough coordination to realize their goals.

In sum, interpersonal networks have an important effect on a variety of important individual outcomes: getting a job, gaining influence, performing well, and getting promoted. As our review indicates, network researchers have typically focused on outcomes, taking available network structures as given. Although similarity, personality, proximity, and organizational structure have been shown to affect interaction patterns within organizations, more work is needed on network antecedents. For example, individuals with critical human capital (expertise, intelligence, skills) and social capital (connections to others) may be particularly attractive partners. Taking a multilevel perspective, we need to locate interpersonal networks within the larger contexts of organizations, looking at the effects of both interunit and interorganizational linkages.

\section{INTERUNIT NETWORKS}

An organization can be conceptualized as a network in which organizational units are nodes interacting with each other, establishing formal and informal relationships. Formal relationships include ties mediated by work flow, resource exchange, and personnel transfer (Ghoshal \& Bartlett, 1990; Nohria \& Ghoshal, 1997); informal relationships include those whereby members of different units seek personal advice from or make friends with each other (Kilduff \& Tsai, 2003). The organizational work units of interest include groups, divisions, business units, and subsidiaries. These units represent part of the context in which interpersonal relationships are embedded. It is important to consider the unit or group context in each organization when examining interpersonal network linkages, as the meanings of such linkages may vary (Emirbayer \& Goodwin, 1994). Investigating network linkages 
of organizational units not only advances knowledge of social networks, but also contributes to understanding of organizational design (Pearce \& David, 1983).

\section{Antecedents of Interunit Networks}

Interpersonal ties. The emergence and formation of ties among organizational units can be attributed to organizational characteristics and operations as well as to individual characteristics. Ties between people in different units are especially intriguing, because they create ties between organizational units, illustrating the "duality" of groups and individuals (Breiger, 1974). When two individual interact, they not only represent an interpersonal tie, but they also represent the groups of which they are members. Thus, interunit ties are often a function of interpersonal ties, and the centralities of units are a function of their members' connections (Bonacich, 1991). The simultaneous mapping of units as well as individuals can contribute to a better understanding of both interpersonal and interunit networks.

Ties between organizational units are often created by powerful individuals, such as the units' leaders, who are involved in decisions about interunit activities (e.g., Knoke, 2001). Several scholars have shown how individual differences in cognition and personality relate to the origins and formation of interunit networks (e.g., Kilduff \& Tsai, 2003). Research on social capital has suggested that individuals' personal connections that cross their own group or organizational boundaries contribute to the social capital of their groups or organizations (e.g., Burt, 1992; Coleman, 1990; Uzzi, 1996).

Functional ties. A tie between two units can also be based on unit-level considerations. For example, a unit's size, performance records, and resource endowments can influence its decision to form a tie with other units and the attractiveness of the unit as a partner for other units. As resource dependence theory has suggested, a unit is likely to be motivated to form a tie with other units that have complementary resources. Also, research on multiunit organizations has shown that two units are likely to form a tie when their resources are strategically related (Tsai, 2000). Units that are more central in a resource exchange network are quicker than others to establish interunit linkages with a newly formed unit (Tsai, 2000), and units with more knowledge communicate more (Schulz, 2001).

Organizational processes and control mechanisms. In addition to individual-level and unitlevel factors, certain organizational processes, rou- tines, or control mechanisms may affect the interactions between units. The design of operational processes influences the opportunities for different units to interact with one another. Also, the extent to which an organization uses control mechanisms to achieve centralization can have a negative impact on the formation of cooperative ties among organizational units. Greater centralization prevents a unit from exercising discretion in dealing with its task environment and reduces the initiatives that it can take in forming interunit knowledge-sharing ties (e.g., Tsai, 2002).

In sum, the intersection of individual-, unit-, and organization-level characteristics and processes suggests many avenues for examining work-unit network antecedents. It also highlights the importance of investigating the connections among crosslevel network phenomena for unraveling complex network dynamics in the organizational settings.

\section{Consequences of Interunit Networks}

Performance. Network ties within and across organizational units have significant impact on unit and organizational performance outcomes. Mehra and his colleagues (2003) showed that unit leaders' network ties with peers and higher-level managers in an organization positively affected unit performance. Reagans and Zuckerman (2001) found that organizational units that had more dense networks achieved a higher level of productivity than those with sparse networks. Oh, Chung, and Labianca (2004; this issue) found that highperformance work teams had moderately cohesive ties internally or many bridging ties to formal leaders in other groups. Also, Reagans, Zuckerman, and McEvily (2004) found that organizational units with high internal density and large external range finished projects more quickly. In a simulation, Krackhardt and Stern (1988) found that friendship ties across groups provided coordination in responding to crises.

Many studies have shown how group performance is influenced by the structure of formal (Guzzo \& Shea, 1992) and informal intergroup networks (Shaw, 1964). As noted above, most studies tend to focus on positive or neutral relations when examining intergroup networks, and only a few scholars have looked at negative relations (Labianca \& Brass, 2004). It could be that negative relations across groups are more important than positive relations in predicting group outcomes. In a study of intergroup networks in 20 organizations, Nelson (1989) found that organizational conflict was negatively related to the percentage of friendship ties that crossed group boundaries. In contrast, Labianca, Brass, and Gray 
(1998) found that friendship ties across groups were not related to perceptions of conflict. Rather, negative relationships (in which one person indicated preferring to avoid another) were related to higher perceived interunit conflict. They made the case for negative asymmetry-the idea that negative events and relationships have more impact on people than positive events or relationships (Labianca \& Brass, 2004). The importance of studying negative relations was also highlighted by Sparrow, Liden, Wayne, and Kraimer (2001), who showed that the density of "hindrance networks" was negatively related to group performance.

Innovation and knowledge activities. Innovation- and knowledge-related activities are likely to be influenced by patterns of interunit ties. Given the existence of allied groups or blocks of business units within multiunit firms, network research can inform about how units share resources with other units to enhance innovation (Kilduff \& Tsai, 2003; Tsai, 2001). Organizational units that are more central in an interunit resource exchange network tend to produce more product innovations (Tsai \& Ghoshal, 1998). Social ties between units facilitate knowledge sharing for units that compete in the same market segments (Tsai, 2002). Strong ties between business units facilitate the transfer of complex knowledge, whereas weak ties are sufficient for less complex knowledge (Hansen, 1999).

In sum, characteristics of personal networks crossing work-unit boundaries affect both interunit conflict and unit performance and innovativeness. Negative ties appear to be highly consequential, perhaps more so than positive ones, and deserve further investigation.

\section{INTERORGANIZATIONAL NETWORKS}

Our discussion of interorganizational networks is limited to long-term cooperative relationships between organizations and suppliers, customers, competitors, and other organizational actors in which organizations retain control over their own resources but jointly decide on their use (Ebers, 1997). In these partnerships, problems are typically resolved through discussion, and rules and norms of reciprocity ensure cooperation (Powell, 1990; Uzzi, 1997). Examples of interorganizational cooperation include joint ventures, strategic alliances, joint programming, collaborations, business groups, consortia, relational contracts, and some forms of franchising and outsourcing (Podolny \& Page, 1998). We do not review the extensive literatures on mergers and acquisitions, board interlocks (Mizruchi, 1996), and competition except as they relate to interorganizational cooperation.

\section{Antecedents of Interorganizational Networks}

Many of the variables that explain the formation of interpersonal and interunit networks explain the creation of interorganizational networks as well. This is not surprising, since interorganizational relations are often initially created by "boundary spanners." Early research focused on motives behind cooperation, but later research has focused on the conditions facilitating cooperation, such as learning, trust, norms, equity, and context.

Motives. Galaskiewicz (1985) cited four motives behind interorganizational cooperation: acquire resources, reduce uncertainty, enhance legitimacy, and attain collective goals (see also Oliver, 1990). Business strategy scholars have argued that interorganizational ties such as strategic alliances, joint ventures, and long-term buyer-supplier partnerships are vehicles that provide a firm with access to "information, resources, markets, and technologies; with advantages from learning, scale, and scope economies; and allow firms to achieve strategic objectives, such as sharing risks and outsourcing value-chain stages and organizational functions" (Gulati, Nohria, \& Zaheer, 2000: 203; see also Alter \& Hage,1993; Ebers, 1997). According to transaction cost analysis, interorganizational forms are ways to reduce opportunistic behavior on the part of suppliers and distributors (Williamson, 1991).

Learning. Firms that have more experience working with other organizations are more likely to form new and more diverse network ties and to become dominant players in networks. Powell, Koput, and Smith-Doerr (1996) found that dedicated biotechnology firms that had more networking experience subsequently gained more knowledge, had more diverse network portfolios, and became more central in collaborative networks. Ahuja (2000) found that chemical firms that had more interfirm ties subsequently were more likely to form joint ventures based on new technologies. Firms learn not only about an industry but also about networking when they engage in alliances, and this knowledge makes them attractive network partners.

Trust. Many researchers acknowledge the importance of trust in building interorganizational networks, but it is difficult to measure trust a priori and to assess its effect on interorganizational cooperation. Zaheer, McEvily, and Perrone (1998) drew the distinction between interpersonal trust between two boundary spanners and interorganizational trust where a boundary spanner in one organization trusts the other organization (but not a particular individual). Although ties may originate because of the former, the success of interorganiza- 
tional cooperation depends on the latter. In their study of buyer-supplier dyads in the electrical equipment manufacturing industry, Zaheer and his coauthors found that, independent of interpersonal trust, a buyer's trust in a supplier organization reduced negotiation costs and conflict and was associated with better supplier performance.

Rousseau, Sitkin, Burt, and Camerer (1998) distinguished between deterrence, calculative, institutional, and relational trust. Most researchers have focused on relational trust, in which the parties will use information from prior interactions to judge each other's reliability. Eisenhardt and Schoonhoven (1996) found that firms with large top management teams, or with top managers who were also employed by other industry employers, or with top managers who were higher ranking executives in other firms were more likely to form strategic alliances. Top management team social capital translated directly into interorganizational alliances. Gulati (1995a) and Chung, Singh, and Lee (2000) found a curvilinear (inverted U-shaped) relation between number of prior alliance ties and the formation of future ties. Levinthal and Fichman (1988) also found a curvilinear (inverted U-shaped) relationship between the length of an auditor-client relationship and the hazard of that relationship ending.

Prior ties seem to be particularly important under conditions of uncertainty. Gulati (1995b) found that non-equity-based (i.e., riskier) alliances in the biopharmaceutical, new materials, and automobile industries were more tightly coupled to the number of previous alliances between the partners than were equity-based alliances. In a similar vein, Beckman, Haunschild, and Phillips (2004) found that large service and industrial firms experiencing greater market uncertainty were more likely to form alliances and interlocks (sharing of board members) with firms with which they had previously aligned themselves or interlocked. Keister (2001) found that in the early stages of China's economic reform, a period of great uncertainty, firms tended to form ties within a business group with firms and managers with whom they had prior ties outside the business group. Rosenkopf, Metiu, and George (2001) found that interaction between midlevel managers in cross-firm technical committees led to subsequent alliance formation among cellular service providers and equipment manufacturers, but the effect decreased as firms gained more experience with one another and thus had better information on their partners.

Although prior networking and close ties can enhance trust, it is possible that actors can become overly embedded in their networks, become risk averse, and continue to work with others because of the strong ties among boundary spanners. Overembedded actors may miss cost-effective opportunities with other actors. In their study of tie dissolution, Seabright, Levinthal, and Fichman (1992) found that attachments among boundary spanners decreased the likelihood of terminating firm-auditor relations, and these ties attenuated the effect of changes in clients' resource needs on switching auditors. However, in a study of advertisers and advertising agencies, Baker, Faulkner, and Fisher (1998) found that the departure of the advertisers' top executives had little effect on the termination of dyadic ties with agencies. Dissolution was sensitive to changes in market conditions.

Norms and monitoring. Even if actors trust each other, problems will arise in the course of collaboration. Hierarchy is certainly one solution for settling disputes (Williamson, 1975); however, Ostrom (1990) and Coleman (1990) stressed the importance of reciprocity norms, and Kogut (2000) noted the importance of rules of behavior that, in turn, create network identities. Ostrom (1998) reviewed an extensive body of empirical work that showed that people cooperate when they can communicate beforehand, learn reciprocity norms, and punish those that deviate. Reciprocity norms and rules can become heuristics that actors evoke in relating to others. Larson (1992) found a similar pattern in her qualitative study of dyads formed by high-growth entrepreneurial firms. Over time actors collaborated, but social controls arising from norms of trust and reciprocity, not formal contracts, governed this collaboration.

Network structure can help enforce norms and rules. Coleman (1988) argued that the benefit of closure, the condition in which an actor $a$ 's network ties are dense and redundant, is that information (or gossip) about the uncooperative behavior of a second actor, $b$, circulates more readily among third parties, (c's), who can then mobilize sanctions against the uncooperative actor in cooperation with actor $a$. A third-party $c$ not only keeps track of b's performance but can threaten to withdraw from interaction with $b$ as well (Putnam, 1993). Because networks can pass on information about others' behaviors, it is reasonable to expect that the presence of third parties can motivate cooperation between two collaborators (Putnam, 1993). This rationale applies at the interorganizational as well as the interpersonal level of analysis.

There is evidence to support this argument. In the three industries he studied, Gulati (1995b) found that if two actors were both cooperating with a third, the likelihood that these two would form a new cooperative relationship with each other in the 
future was greater. Gulati argued that actors can learn about others' tendencies through their cooperative ties with third parties that in turn assure them about approaching these parties themselves (see also Granovetter, 1985). Similarly, Rowley, Greve, Rao, Baum, and Shipilov (in press) found that higher density within an interorganizational clique led to fewer exits from the clique.

Equity. There is evidence that interorganizational collaborations are more likely if partners have similar status and power (Ostrom, 1990; Ring \& Van de Ven, 1992). DeLaat (1997) noted that unless $b$ can reciprocate the gesture extended by $a$, $a$ is unlikely to enter into a cooperative relationship with $b$. Such entry would require a unilateral commitment on $a$ 's part. In turn, if $a$ extended favors to $b, b$ would incur obligations to $a$ that he could not pay back, and thus $b$ would avoid collaborating with $a$. As Emerson (1962) argued, the power differential between $a$ and $b$ creates an unstable situation for $b$. If problems in the relationship arise, $a$ has all the power to resolve them as she or he sees fit.

Chung, Singh, and Lee (2000) found that investment banks were more likely to form syndicates to underwrite corporate stock offerings if their statuses were similar. Rowley and colleagues (in press) found that an investment bank was more likely to leave syndication cliques that had unequal power relations, especially if the bank was weak relative to the others. Gulati and Gargiulo (1999) reported that two firms were likely to form a strategic alliance if both were central in a relevant interorganizational network of alliances (but not if they were both peripheral). Han and Breiger's (1999) reanalysis of Eccles and Crane's (1988) syndicate data for U.S. investment banks showed that firms that put together deals were status equals (see also Podolny, 1993). Although these findings may seem like confirmations of the similarity hypothesis found in the interpersonal network studies, we suspect that the findings result from the problems of negotiating cooperative relationships among actors with different capabilities and power.

Context. Other researchers have focused on the broader cultural, historical, and institutional context to explain interorganizational networks. For example, changes in the U.S. regulatory environment, such as the National Cooperative Research Act, enabled coordinated research and development activity among market competitors to an extent unseen previously (Podolny \& Page, 1998). Firms were cooperating before this regulatory change, but this and other legislation legitimated cooperation among competitors. Powell (1990) gave numerous examples of how culture, local so- cial and business organizations, and institutional arrangements were critical in explaining the formation of interorganizational networks both in the United States and abroad. Saxenian (1994) explained variation in regional development focusing on local subcultures, and Marquis (2003) explained patterns of local corporate interlocking focusing on community institutions and local histories. Scott (1987) showed that the different forms of interfirm relations in Britain, France, and Germany can be traced to their distinct patterns of historical development. Much of the new institutional research on interfirm structures in East Asia has accounted for variations in network structures by focusing on cultural, political, and historical contexts (see Gerlach, 1992; Hamilton \& Biggart, 1988; Keister, 2000). The evidence, however, is mixed on whether cultural differences hinder cross-national collaborations. In an analysis of international joint ventures by large Dutch firms, Barkema, Shenkar, Vermeulen, and Bell (1997) found that the duration of these joint ventures was inversely related to the social distance between the firms and their partners. In contrast, Park and Ungson (1997) found that cultural distance was unrelated to joint venture dissolution rates. However, both studies concluded that cultural differences can be overcome if firms gain experience partnering with others and working across international borders (see also Contractor \& Lorange, 1988).

"Conveners" are another exogenous influence (Wood \& Gray, 1991). These include government agencies, foundations, and industry leaders who attempt to build networks among organizational actors (Doz, Olk, \& Ring, 2000). McEvily and Zaheer (1999) studied the role of regional institutions in developing local networks for manufacturers, the propensity of manufacturers to participate in these networks, and the effect of their participation on their competitive capabilities. Human and Provan (2000) studied how network brokers and administrators helped to build networks and network credibility among small manufacturing enterprises in the U.S. wood products industry. Lütz (1997) studied an effort at network building by the German Federal Ministry for Research and Technology and showed how scientific partners acted as brokers between manufacturers and provided information that became the building block for future collaborations. Kogut (2000) and Dyer and Nobeoka (2000) described how Toyota built its production system and monitored its behavior. When organizations do not have compelling motives to collaborate, outside intervention may be necessary for networks to form and will shape how they form. 


\section{Consequences of Interorganizational Networks}

Imitation. Network ties transmit information and are thought to be especially influential information conduits because they provide salient and trusted information that is likely to affect behavior. The proposition that information transmission leads to imitation is found in institutional theory (DiMaggio \& Powell, 1983) and organizational learning theory (Levitt \& March, 1988), and it has led many to investigate the effects of networks on the mimetic adoption of practices. Considerable evidence that imitation follows network ties among organizations exists (Ahuja, 2000; Chaves, 1996; Davis \& Greve, 1997; Galaskiewicz \& Burt, 1991; Galaskiewicz \& Wasserman, 1989; Greve, 1996; Haunschild \& Beckman, 1998; Hedström, Sandell, \& Stern, 2000; Henisz \& Delios, 2001; Palmer, Jennings, \& Zhou, 1993; Rao et al., 2000; Westphal \& Zajac, 1997). The evidence covers a broad range of study populations and behaviors, and the work has expanded from investigating the diffusion of technologies and institutions to examining the diffusion of competitive strategies.

Networks speed up diffusion, even of practices that are widely known. Thus, networks do not cause adoption of practices solely through awareness. Network ties also provide information on costs and benefits of adoption at a greater level of detail and persuasiveness than other information sources do. Using a computational approach, Gibbons (2004; in this issue) showed how different structures of network ties affect the diffusion of different innovation practices in organizational fields. Networks also affect the diffusion of behavior norms. When behaviors are controversial or risky, network actors that have experienced a similar decision may take sides and provide persuasion (Davis \& Greve, 1997; Westphal \& Zajac, 1997). Indeed, the diffusion of norms for behavior seems to operate through activation of network ties when a focal actor is facing a problem and is uncertain about the best response (McDonald \& Westphal, 2003).

Network diffusion is amplified by similarity of social, organizational, or strategic characteristics of organizations because the managers in adopting organizations see similar organizations as more relevant and easier to learn from (Ahuja \& Katila, 2001; Davis \& Greve, 1997; Haunschild \& Beckman, 1998; Soule, 1997; Westphal, Seidel, \& Stewart, 2001). The proposition that competition among actors with similar statuses is a driving force of imitation (Burt, 1987) has led to comparison of contact (the existence of a network tie) with structural equivalence as explanations of imitation, with some work finding structural equivalence having more explanatory power (Galaskiewicz \& Burt, 1991). Contact hypotheses have been tested more frequently, however, and they have solid empirical support (Ahuja, 2000; Chaves, 1996; Davis \& Greve, 1997; Galaskiewicz \& Wasserman, 1989). Like similarity of characteristics, structural equivalence may amplify diffusion from contacts rather than replace it.

Innovation. The industrial district literature claims that firms in close proximity to each other gain knowledge spillovers (Jaffe \& Adams, 1996; Saxenian, 1994), but it usually does not offer direct evidence on this process. Recently network research has shown that research scientists indeed use strong and weak ties to share knowledge across organizational boundaries, particularly if their organizations are not direct competitors (Bouty, 2000), and formal collaborative ties between firms increase the innovation output of biotechnology start-up firms (Baum, Calabrese, \& Silverman, 2000; Powell et al., 1996; Shan, Walker, \& Kogut, 1994). A broad survey of young technology-based firms showed that interaction with their main customers and obtaining customers through the main customers' networks had a positive association with new product development (Yli-Renko, Autio, \& Sapienza, 2001). Networks shape not just innovation output, but also innovation input such as R\&D investment. In a study of alliance networks in the U.S. computer and telecommunication industry, Soh, Mahmood, and Mitchell (2004; in this issue) showed how network centrality moderates the relationship between product awards and change in R\&D investments.

Closer inspection of network structures has yielded additional findings. An important debate is whether information collection is more efficiently done in networks with closure or in networks with structural holes. Closed networks, where direct ties are also tied to each other, generate trust (Coleman, 1988); networks with structural holes, where direct ties are not themselves connected and are tied to different portions of the networks, give access to diverse knowledge (Burt, 1992, 2001). Ahuja's (2000) study of chemical firms showed that patenting rates increased when firms had many ties to firms that were themselves interconnected, indicating a positive effect of information access on innovativeness, but that structural holes reduced innovation rates. These findings seem to support a closure view but not a structural holes view. On the other hand, Baum and his colleagues (2000), in work on biotechnology firms, showed that networks giving access to diverse information had a positive effect on patenting rates. And in Ruef's (2002) study, members of start-up teams evaluated 
their own ideas as more innovative if they had diverse networks and many discussions with weak tie contacts, though these findings did not hold up when the dependent variable was the probability of applying for a patent.

The tension between the knowledge diversity offered by structural holes and the trust offered by cohesion can also be resolved through embedding networks in structures that generate trust. Such structures include spatial proximity, access to a common labor market, and central organizations committed to information sharing (Owen-Smith \& Powell, 2004).

Firm survival. The positive effects of network ties on the information access of a firm suggest that network ties might yield positive outcomes such as firm survival. The theory of the liability of newness, according to which a lack of stable exchange relations and a lack of access to resources make new firms particularly prone to fail (Stinchcombe, 1965), gives reason to examine the effect of network ties on the survival chances of new firms. This effect is difficult to show in aggregate data (e.g., Bates, 1990), but studies have shown a positive effect of ties on the survival chances of newly founded firms (Brüderl \& Preisendörfer, 1998; Hager, Galaskiewicz, \& Larson, 2004) and firms engaging in major changes (Miner, Amburgey, \& Stearns, 1990).

Network ties with legitimated symbols in an organizational field also affect survival. Baum and Oliver (1991) found that day care centers with more ties to community organizations and government agencies had much lower death rates. Singh, Tucker, and Meinhard (1991) found that voluntary social service organizations that had listings in community directories, charitable registration numbers, and large boards of directors had significantly lower death rates. Being linked to legitimate actors may be especially beneficial in markets where output is difficult to evaluate directly.

Distinguishing the strength of ties yields additional findings on network effects on survival. Embedded ties are those with which an actor has a high proportion of exchanges and close interaction, as opposed to less frequent, less close arm's-length ties. Analysis of the failure rates of apparel manufacturers in New York showed that firms with a high proportion of embedded ties to firms with mixtures of embedded and arm's-length ties had lower failure rates (Uzzi, 1996). The firms appeared to benefit both from the broader information collection that arm's-length ties provided and from the trust that embedded ties provided, thus suggesting that a balance of strong and weak ties is most effective (Uzzi, 1997).
Performance. The conditions that lead to higher survival rates may also result in higher performance. Indeed, strong and weak tie support increases sales growth for new businesses (Brüderl \& Preisendörfer, 1998). In the technology-based startups studied by Lee, Lee, and Pennings (2001), however, ties to external actors increased sales growth for firms with high internal capabilities but had virtually no independent (main) effect, suggesting that network ties helped firms realize the value of internal capabilities but were not a way of obtaining capabilities. A main effect can still be obtained when visible network ties are interpreted as a signal of quality that confers status on a firm, and thus increase the price of its products or services (Podolny, 1993, 1994) and of its stock (Stuart, Hoang, \& Hybels, 1999).

Studies have also examined the effects of different network structures on performance. Centrality in an interorganizational network and experience with collaborations increased the growth rate of biotechnology start-ups (Powell et al., 1996). Biotechnology start-ups with networks giving access to diverse information had higher revenue growth (Baum et al., 2000), but the effect seemed dependent on the type of actor a start-up was tied to (Silverman \& Baum, 2002). Clique structures could be identified through the transactions of Canadian investment banks, and cliques whose members had diverse specializations but similar network centrality obtained high market shares for their members (Rowley, Baum, Shipilov, Greve, \& Rao, 2004).

Debate continues about the effects of strong and weak ties and brokerage and network cohesion on performance. Rowley, Behrens, and Krackhardt (2000) found that strong ties increased performance in the relatively stable steel industry, whereas weak ties increased performance in the more dynamic semiconductor industry. Thus, weak ties that facilitate information collection are more valuable when there is much information to collect, while strong ties are more important when firms seek to reduce competitive intensity in stable industries. In a study of hotels in Sydney, Ingram and Roberts (2001) replicated this last finding; they found that friendship ties with competitors increased room yields, particularly when demand was low, as did cohesive ties among competitors. In other work, brokerage and cohesion effects have been found to operate together. Organizations obtain better returns when they are in a position to broker between disconnected others and also when they and a powerful actor are connected within a cohesive set of organizations tied to each other (Bae \& Gargiulo, 2004; in this issue). This formulation suggests that 
ties to resource-rich organizations carry costs unless ties to third parties are used to gain leverage.

Researchers have also studied performance or effectiveness at the interorganizational network level. As governance structures, networks can produce either positive or negative externalities-both for network members and for outsiders-depending on how they are structured or organized (see, for example, Lincoln, Gerlach, and Ahmadjian [1996]). One issue is whether centralized or decentralized networks work better. In a study of business groups in China, Keister (1998) found that extensive interlocking directorates and nonhierarchical organizational structures enhanced the financial performance of member firms. Research on networks of human service organizations has shown that centralization decreased effectiveness as perceived by providers (Alter \& Hage, 1993) but increased effectiveness as perceived by users (Provan \& Milward, 1995), suggesting a need for additional work.

It may be that decentralized networks are superior when they are organized according to "smallworld" principles (Watts, 1999). According to this school of thought, the best network has local clustering into dense subnetworks, short paths between all actors, and relatively few ties. Such networks are effective because bridges span dense clusters and connect different parts, so that resources "hop" from cluster to cluster (Uzzi \& Spiro, 2004). The engineering task is to "rewire" a network so that there are "short cuts" between clusters that minimize the average path distance (Watts \& Strogatz, 1998). Empirical work on such overall network properties is promising. For example, Madhavan, Gnyawali, and He (2004; in this issue) found that interorganizational networks in the steel industry had many transitive triads (triads in which each firm was linked to both of the others), particularly among producers with the same technology or geographical origin. Small-world patterns have also been found in investment bank syndicate networks in Canada (Baum, Shipilov, \& Rowley, 2003), ownership networks among German firms (Kogut \& Walker, 2001), and board-interlocked networks in the United States (Davis, Yoo, \& Baker, 2003). Even more recent work suggests that industries with small-world networks perform better (Schilling \& Phelps, 2004; Uzzi \& Spiro, 2004).

In sum, interorganizational networks are created by some of the same mechanisms that create interpersonal networks, as well as by distinct mechanisms. Like individuals, organizations extend ties in the direction of valuable information and resources, but organizations are constrained by their managers' levels of experience and of trust in po- tential contacts. Unlike individuals, moreover, organizations are strongly affected by competitive market relations. These considerations also affect the consequences of membership in interorganizational networks. Networks are stable if they serve the interests of their constituent organizations. Interorganizational networks offer a variety of knowledge, innovation, performance, and survival benefits, but the issues of competition, information control, and trust in partners makes the problem of building effective networks highly complex.

\section{DISCUSSION}

As our review has shown, networks have many of the consequences that have been predicted: (1) they transfer information that gives rise to attitude similarity, imitation, and generation of innovations; (2) they mediate transactions among organizations and cooperation among persons; and (3) they give differential access to resources and power. These basic findings have been replicated, and researchers have begun to progress to more difficult issues, taking into account network dynamics across different levels.

At all levels of networking, the joint influence of opportunities (especially sought-after information and resources) and constraints (especially past actions and uncertainty) on network reproduction and change are apparent. For example, events exogenous to networks can either reinforce or loosen structure in interorganizational (Madhavan, Koka, \& Prescott, 1998) and in intraorganizational (Shah, 2000) networks. Endogenous factors include information spillovers that benefit actors and stimulate new linkages (Bouty, 2000; Owen-Smith \& Powell, 2004). Network changes can be explained by rules of attachment (for example, "link with those that are linked to others, or with those that are different from oneself") that affect subsequent network evolution (Powell, White, Koput, \& Owen-Smith, in press). These same rules are seen to evolve in interpersonal relationships and in power relationships within organizations (Brass, 1984). In a study of the Italian TV production industry, Soda, Usai, and Zaheer (2004; in this issue) took a different approach to studying structural change. They showed that current structural holes rather than past ones, but past closure rather than current closure, helped current network performance.

Actors' characteristics can also have an impact on changes in interpersonal, interunit, and interorganizational networks (Chung et al., 2000; Klein et al., 2004; Mehra et al., 2001; Rowley et al., in press; Tsai, 2000). Actor characteristics, such as resources and capabilities, determine the type of network 
most useful to an actor and its ability to create such a network. Individual characteristics, such as personality and work unit, and organizational characteristics, such as resources, are potential moderators of network effects. The tension between the hope of acquiring new capabilities and the fear of losing control over one's own resources may help to explain network reproduction and change at both the interpersonal and interorganizational levels of analysis (Burt, 1992; Das \& Teng, 2000; de Rond \& Bouchikhi, 2004). This is especially the case when organizations find themselves cooperating with competitors, departments cooperating with other departments, and managers cooperating with peers.

Understanding network change requires understanding cross-level pressures. Networks themselves are embedded in larger contexts (Granovetter, 1985), and to understand how the networks change, analysts need to understand the larger contexts. Individuals work within departments or work units, work units are parts of larger organizations, and organizations are parts of industries. Changes taking place at the industry level have repercussions at the organizational, work-unit, and individual levels, and vice versa. For example, individual job satisfaction may be a function of the network of interpersonal relations within a work unit, the position of the work unit within its organization, and the position of the organization within its industry. The performance of firms may depend on their networks of collaboration at the industry level. Collaboration among firms may be the result of collaboration among individuals. Conversely, the performance of individuals may depend on the networks of collaboration among work units. Changes in interpersonal networks within a work unit may be contingent upon changes in an organization. As organizations grow by adding more units, their networks of internal relations increase. On the other hand, as organizations downsize or divest assets, the network ties between personnel and departments are disrupted.

Researchers looking to explain cross-level network change should also be aware of the duality of group structures (Breiger, 1974). Actors are linked by being in the same group (a department or an industry for instance), and they in turn link the different groups of which they are members. Some actors are critical in maintaining or increasing the integration among groups, since their departure would severe the ties between groups. Similarly, some groups (e.g., cross-functional teams and industry associations) are critical because they provide an opportunity for members of different groups to form interpersonal ties. Actors who per- form these bridging roles are likely to know more and to have influence in the larger, external network, but they may be peripheral (and expendable) to the internal networks of the groups they belong to (see, for example, Fernandez and Gould [1994] for a discussion of different brokerage roles based on individual actors' group memberships). Groups whose members have connections to other groups are likely to be more innovative, but they may have much weaker member identity and less member loyalty. There is a considerable amount of research to be done on these issues, since ties between actors in organizational and interorganizational networks may change as actors come and go.

The duality principle has also been used to study firm behaviors and outcomes within markets. McPherson (1983) showed how structurally equivalent sets of competitors within organizational fields can be identified by looking at who consumes the products and services of which providers (members and voluntary associations, in his example). Niche composition and overlap, in turn, affected whether voluntary associations grew or shrunk (McPherson et al., 1992), and whether firms survived (Baum \& Singh, 1994). The decisions of firms may be affected by their peers with respect to both selling and buying networks (White, 2001), just as individuals are affected by their peers (Burt, 1992). Venkatraman and Lee (2004; in this issue) found that software developers were less likely to launch products on manufacturers' platforms when other developers and titles had strong presencesthat is, when niche overlap was high.

Alternatively, niche overlap provides a strong incentive for collusion and the creation of ties among structural equivalents (Galaskiewicz \& Zaheer, 1999). Given that competitors have an interest in reducing the advantage of those upon whom they depend (Burt, 1992), niche overlap provides an incentive for competitors to share information on customers (Ingram \& Roberts, 2001), engage in joint ventures and strategic alliances (Stuart, 1998), and interlock (Burt, 1983). Research on multimarket competition has examined how the network of market contacts between firms generates weaker competition, higher prices, and higher survival rates (Greve \& Baum, 2001).

When competitors form alliance ties with each other, they may also try to gain advantage over a competitor outside their alliance (Gargiulo, 1993). The potential of using alliances with competitors to defeat other competitors raises the possibility of alliance networks competing with other alliance networks. Gimeno (2004; in this issue) showed that when alliances involved specialized investments, competitors of the alliance partners tended to be 
excluded from a network. Thus, heavily invested alliance structures lead to clustering and internetwork competition as managers weigh the different motivations for forming alliances and act differently depending on how their motivations balance out. Much of the research on alliance formation and niches might fruitfully be extrapolated to the interpersonal and interunit levels of analysis. Do individuals create niches and form alliances within organizations? Are the motives for alliance formation the same at the interpersonal level as they are at the interorganizational level?

Finally, studying network change is critical, because cross-sectional analyses of networks often leave causal relations ambiguous. For example, when examining the effect of network ties on interorganizational learning, one often sees more learning from similar contacts. However, ties are also more likely to be established between similar actors, so it is difficult to partition the effect of the similarity that caused a tie to be established and the effect of the tie itself. As another example, when seeking to find effects of interpersonal networks on job promotions, it is expedient to take a cross section of current networks and use archival data on past promotions. This procedure, however, makes the independent variable temporally posterior to the outcome and carries particular risks because managers may change their networks after a promotion in order to fulfill their new responsibilities. Thus, it becomes impossible to discern whether the networks of promoted managers were the cause or the consequence of the early promotions. We suspect that the relationship is reciprocal: networks create outcomes that are, in turn, antecedents for further network development.

\section{CONCLUSION}

Organizational network research offers a rich set of findings, rapid progress, and unresolved theoretical and empirical questions. It bears all the marks of a research tradition that will continue to flourish. In recent work we have detected some shifts of emphasis that will continue to enrich network research by filling important gaps in our knowledge. These shifts are very healthy, and we list them here to encourage them as well as to document them: (1) There has been a shift from examining absolutes to looking at trade-offs; this shift has occurred because the absolutes (such as easier information transfer through network ties) have already been documented and are now less interesting than the trade-offs (such as seeking to gain information while not giving too much away). (2) There has been a shift from statics to dynamics, inspired both by the better evidence offered by longitudinal research and by interest in how networks change. (3) There has been a shift from single levels of analysis to analysis showing effects crossing levels, inspired by the realization that networks are affected both from below (for instance, by individual characteristics) and from above (even networks have environments). (4) There has been a shift from simple binary considerations, such as the existence or nonexistence of a relationship, to consideration of distinctions, such as the strength and content of the relationship, because such a level of detail is often needed to distinguish theoretical predictions. Although network research in organizations is already such a large research tradition that it is getting difficult to review, these recent shifts can be expected to fuel many future investigations.

\section{REFERENCES}

Ahuja, G. 2000. Collaboration networks, structural holes, and innovation: A longitudinal study. Administrative Science Quarterly, 45: 425-455.

Ahuja, G., \& Katila, R. 2001. Technological acquisitions and the innovation performance of the acquiring firms: A longitudinal study. Strategic Management Journal, 22: 197-220.

Alter, C., \& Hage, J. 1993. Organizations working together. Newbury Park, CA: Sage.

Bae, J.. \& Gargiulo, M. 2004. Partner substitutability, alliance network structure, and firm profitability in the telecommunications industry. Academy of Management Journal, 47: 860-875.

Baker, W. E., \& Faulkner, R. R. 1993. The social organization of conspiracy: Illegal networks in the heavy electrical equipment industry. American Sociological Review, 58: 837-860.

Baker, W. E., Faulkner, R. R., \& Fisher, G. A. 1998. Hazards of the market: The continuity and dissolution of interorganizational market relationships. American Sociological Review, 63: 147-177.

Barkema, H. G., Shenkar, O., Vermeulen, F., \& Bell, J. H. J. 1997. Working abroad, working with others: How firms learn to operate international joint ventures. Academy of Management Journal, 40: 426-442.

Bates, T. 1990. Entrepreneur human capital inputs and small business longevity. Review of Economics and Statistics, 72: 551-559.

Baum, J. A. C., Calabrese, T., \& Silverman, B. S. 2000. Don't go it alone: Alliance network composition and startups' performance in Canadian biotechnology. Strategic Management Journal, 21: 267-294.

Baum, J. A. C., \& Oliver, C. 1991. Institutional linkages and organizational mortality. Administrative Science Quarterly, 36: 187-218.

Baum, J. A. C., Shipilov, A. V., \& Rowley, T. J. 2003. 
Where do small worlds come from? Industrial and Corporate Change, 12: 697-725.

Baum, J. A. C., \& Singh, J. V. 1994. Organizational niche overlap and the dynamics of organizational mortality. American Journal of Sociology, 100: 346-380.

Beckman, C. M., Haunschild, P. R., \& Phillips, D. J. 2004. Friends or strangers? Firm-specific uncertainty, market uncertainty, and network partner selection. Organization Science, 15: 259-275.

Bian, Y. 1997. Bringing strong ties back in: Indirect ties, network bridges, and job searches in China. American Sociological Review, 62: 266-285.

Blau, P. M. 1977. Inequality and heterogeneity. New York: Free Press.

Blau, J. R., \& Alba, R. D. 1982. Empowering nets of participation. Administrative Science Quarterly, 27: 363-379.

Bonacich, P. 1991. Simultaneous group and individual centralities. Social Networks, 13: 155-168.

Borgatti, S. P., \& Cross, R. 2003. A relational view of information seeking and learning in social networks. Management Science, 49: 432-445.

Borgatti, S. P., \& Foster, P. C. 2003. The network paradigm in organizational research: A review and typology. Journal of Management, 29: 991-1013.

Bouty, I. 2000. Interpersonal and interaction influences on informal resource exchanges between R\&D researchers across organizational boundaries. Academy of Management Journal, 43: 50-65.

Boxman, E. A. W., de Graaf, P. M., \& Flap, H. D. 1991. The impact of social and human capital on the income attainment of Dutch managers. Social Networks, 13: 51-73.

Brass, D. J. 1981. Structural relationships, job characteristics, and worker satisfaction and performance. Administrative Science Quarterly, 26: 331-348.

Brass, D. J. 1984. Being in the right place: A structural analysis of individual influence in an organization. Administrative Science Quarterly, 29: 518-539.

Brass, D. J. 1985a. Men's and women's networks: A study of interaction patterns and influence in an organization. Academy of Management Journal, 28: 327343.

Brass, D. J. 1985b. Technology and the structuring of jobs: Employee satisfaction, performance, and influence. Organizational Behavior and Human Decision Making, 35: 216-240.

Brass, D. J. 1995. Creativity: It's all in your social network. In C. M. Ford \& D. A. Gioia (Eds.), Creative action in organizations: 94-99. Thousand Oaks, CA: Sage.

Brass, D. J., \& Burkhardt, M. E. 1992. Centrality and power in organizations. In N. Nohria \& R. Eccles (Eds.), Networks and organizations: Structure, form, and action: 191-215. Boston: Harvard Business School Press.

Brass, D. J., \& Burkhardt, M. E. 1993. Potential power and power use: An investigation of structure and behavior. Academy of Management Journal, 36: 44-470.

Brass, D. J., Butterfield, K. D., \& Skaggs, B. C. 1998. Relationships and unethical behavior: A social network perspective. Academy of Management Review, 23: $14-31$.

Brass, D. J., \& Krackhardt, D. 1999. The social capital of 21st century leaders. In J. G. Hunt, G. E. Dodge, \& L. Wong (Eds.), Out-of-the-box leadership: 179-194. Stamford, CT: JAI Press.

Breiger, R. L. 1974. The duality of persons and groups. Social Forces, 53: 181-190.

Brüderl, J., \& Preisendörfer, P. 1998. Network support and the success of newly founded businesses. Small Business Economics, 10: 213-225.

Burkhardt, M. E. 1994. Social interaction effects following a technological change: A longitudinal investigation. Academy of Management Journal, 37: 869898.

Burkhardt, M. E., \& Brass, D. J. 1990. Changing patterns or patterns of change: The effect of a change in technology on social network structure and power. $\boldsymbol{A d}$ ministrative Science Quarterly, 35: 104-127.

Burt, R. S. 1982. Toward a structural theory of action. New York: Academic Press.

Burt, R. S. 1983. Corporate profits and cooptation: Networks of market constraints and directorate ties in the American economy. New York: Academic Press.

Burt, R. S. 1987. Social contagion and innovation: Cohesion versus structural equivalence. American Journal of Sociology, 92: 1287-1335.

Burt, R. S. 1992. Structural holes: The social structure of competition. Cambridge, MA: Harvard University Press.

Burt, R. S. 1997. The contingent value of social capital. Administrative Science Quarterly, 42: 339-365.

Burt, R. S. 2000. The network structure of social capital. In B. M. Staw \& R. I. Sutton (Eds.), Research in organizational behavior, vol. 22: 345-431. Greenwich, CT: JAI Press.

Carley, K. 1991. A theory of group stability. American Sociological Review, 56: 331-354.

Casciaro, T. 1998. Seeing things clearly: Social structure, personality, and accuracy in social network perception. Social Networks, 20: 331-351.

Chaves, M. 1996. Ordaining women: The diffusion of an organizational innovation. American Journal of Sociology, 101: 840-873.

Chung, S. A., Singh, H., \& Lee, K. 2000. Complementarity, status similarity, and social capital as drivers of 
alliance formation. Strategic Management Journal, 21: 1-22.

Coleman, J. S. 1988. Social capital in the creation of human capital. American Journal of Sociology, 94: S95-S120.

Coleman, J. S. 1990. Foundations of social theory. Cambridge, MA: Belknap/Harvard University Press.

Contractor, F. J., \& Lorange, P. 1988. Cooperative strategies in international business. Lexington, MA: Lexington Books.

Cross, R., \& Cummings, J. N. 2004. Ties and network correlates of individual performance in knowledgeintensive work. Academy of Management Journal, 47: $928-937$.

Danowski, J. A., \& Edison-Swift, P. 1985. Crisis effects on intraorganizational computer-based communication. Communication Research, 12, 251-270.

Das, T. K., \& Teng, B. -S. 2000. Instabilities of strategic alliances: An internal tensions perspective. Organization Science, 11: 77-101.

Davis, J. A. 1966. Structural balance, mechanical solidarity, and interpersonal relations. In 3. Berger, $\mathrm{M}$. Zelditch, \& B. Anderson (Eds.), Sociological theories in progress: 74-101. Boston: Houghton-Mifflin.

Davis, G. F., \& Greve, H. R. 1997. Corporate elite networks and governance changes in the 1980s. American Journal of Sociology, 103: 1-37.

Davis, G. F., Yoo, M., \& Baker, W. E. 2003. The small world of the American corporate elite, 1982-2001. Strategic Organization, 1: 301-326.

de Graaf, N. D., \& Flap, H. D. 1988. "With a little help from my friends": Social resources as an explanation of occupational status and income in West Germany, The Netherlands, and the United States. Social Forces, 67: 452-472.

de Rond, M., \& Bouchikhi, H. 2004. On the dialectics of strategic alliances. Organization Science, 15: 5669.

DeLaat, P. 1997. Research and development alliances: Ensuring trust by mutual commitments. In M. Ebers (Ed.), The formation of inter-organizational networks: 146-173. Oxford, England: Oxford University Press.

DiMaggio, P. J., \& Powell, W. W. 1983. The iron cage revisited: Institutional isomorphism and collective rationality in organizational fields. American Sociological Review, 48: 147-160.

Doz, Y. L., Olk, P. M., \& Ring, P. S. 2000. Formation processes of R\&D consortia: Which path to take? Where does it lead? Strategic Management Journal, 21: $239-266$.

Durkheim, E. 1997/1951. Suicide: A study in sociology. (J. A. Spaulding \& G. Simpson, trans.). New York: Free Press.

Dyer, J. H., \& Nobeoka, K. 2000. Creating and managing a high-performance knowledge-sharing network: The Toyota case. Strategic Management Journal, 21: 345-367.

Ebers, M. 1997. Explaining inter-organizational network formation. In M. Ebers (Ed.), The formation of interorganizational networks: 3-40. Oxford, England: Oxford University Press.

Eccles, R.G., \& Crane, D. B. 1988. Doing deals: Investment banks at work. Boston: Harvard Business School Press.

Eisenhardt, K. M., \& Schoonhoven, C. B. 1996. Resourcebased view of strategic alliance formation: Strategic and social effects in entrepreneurial firms. Organization Science, 7:136-150.

Emerson, R. 1962. Power dependence relations. American Sociological Review, 27: 31-41.

Emirbayer, M., \& Goodwin, J. 1994. Network analysis, culture, and the problem of agency. American Journal of Sociology, 99: 1411-1454.

Erickson, B. H. 1988. The relational basis of attitudes. In B. Wellman \& S. D. Berkowitz (Eds.), Social structures: A network approach: 99-121. Cambridge, England: Cambridge University Press.

Fernandez, R. M., Castilla, E., \& Moore, P. 2000. Social capital at work: Networks and hiring at a phone center. American Journal of Sociology, 105: 12881356.

Fernandez, R. M, \& Gould, R. V. 1994. A dilemma of state power: Brokerage and influence in the national health policy domain. American Journal of Sociology, 99: 1455-1491.

Festinger, L., Schachter, S., \& Back, K. 1950. Social pressures in informal groups: A study of human factors in housing. New York: Harper.

Fulk, J., \& Steinfield, C. 1990. Organizations and communication technology. London: Sage.

Galaskiewicz, J. 1979. Exchange networks and community politics. Beverly Hills, CA: Sage.

Galaskiewicz, J. 1985. Interorganizational relations. In R. Turner \& J. Short (Eds.), Annual review of sociology, vol. 11: 281-304. Palo Alto, CA: Annual Reviews.

Galaskiewicz, J., \& Burt, R. S. 1991. Interorganizational contagion in corporate philanthropy. Administrative Science Quarterly, 36: 88-105.

Galaskiewicz, J., \& Wasserman, S. 1989. Mimetic processes within an interorganizational field: An empirical test. Administrative Science Quarterly. 34: $454-479$.

Galaskiewicz, J., \& Zaheer, A. 1999. Networks of competitive advantage. In S. B. Andrews \& D. Knoke (Eds.), Research in the sociology of organizations, vol. 16: 237-261. Stamford, CT: JAI Press.

Gargiulo, M. 1993. Two-step leverage: Managing con- 
straint in organizational politics. Administrative Science Quarterly, 38: 1-19.

Gargiulo, M., \& Benassi, M. 1999. The dark side of social capital. In S. Gabby \& R. Lenders (Eds.), Social capital and liability: 298-322. Norwell, MA: Kluwer.

Gerlach, M. L. 1992. Alliance capitalism: The social organization of Japanese business. Berkeley: University of California Press.

Ghoshal, S., \& Bartlett, C. A. 1990. The multinational corporation as an interorganizational network. Academy of Management Review, 15: 603-625.

Gibbons, D. 2004. Network structure and innovation ambiguity effects on diffusion in dynamic organizational fields. Academy of Management Journal, 47: 938-951.

Gimeno, J. 2004. Competition within and between networks: The contingent effect of competitive embeddedness on alliance formation. Academy of Management Journal, 47: 820-842.

Graen, G. B., \& Scandura, T. A. 1987. Toward a psychology of dyadic organizing. In L. L. Cummings \& B. Staw (Eds.), Research in organizational behavior, vol. 9: 175-208. Greenwich, CT: JAI Press.

Granovetter, M. 1973. The strength of weak ties. American Journal of Sociology, 78: 1360-1380.

Granovetter, M. 1982. The strength of weak ties: A network theory revisited. In P.V. Marsden \& N. Lin (Eds.), Social structure and network analysis: 105130. Beverly Hills, CA: Sage.

Granovetter, M. 1985. Economic action and social structure: The problem of embeddedness. American Journal of Sociology, 91: 481-510.

Greve, H. R. 1996. Patterns of competition: The diffusion of a market position in radio broadcasting. Administrative Science Quarterly, 41: 29-60.

Greve, H. R., \& Baum, J. A. C. 2001. A multiunit, multimarket world. In J. A. C. Baum \& H. R. Greve (Eds.), Multiunit organization and multimarket strategy: 1-28. Oxford, England: Elsevier.

Gulati, R. 1995a. Social structure and alliance formation patterns: A longitudinal analysis. Administrative Science Quarterly, 40: 619-652.

Gulati, R. 1995b. Familiarity breeds trust? The implications of repeated ties on contractual choice in alliances. Academy of Management Journal, 38: 85112.

Gulati, R. 1999. Network location and learning: The influence of network resources and firm capabilities on alliance formation. Strategic Management Journal, 20: 397-420.

Gulati, R., \& Gargiulo, M. 1999. Where do interorganizational networks come from? American Journal of Sociology, 104: 1439-1493.

Gulati, R., Nohria, N., \& Zaheer, A. 2000. Strategic networks. Strategic Management Journal, 21: 203-215.
Guzzo, R. A., \& Shea, G. P. 1992. Group performance and intergroup relations. In M. D. Dunnette \& L. M. Hough (Eds.), Handbook of industrial and organizational psychology (2nd ed.), vol. 3: 269-314. Palo Alto, CA: Consulting Psychologists Press.

Hager, M. A., Galaskiewicz, J., \& Larson, J. A. 2004. Structural embeddedness and the liability of newness among nonprofit organizations. Public Management Review, 6: 159-188.

Hamilton, G. G., \& Biggart, N. W. 1988. Market, culture, and authority: A comparative analysis of management and organization in the Far East. American Journal of Sociology, 94(supplement): S52-S94.

Han, S-K. H., \& Breiger, R. L. 1999. Dimensions of corporate social capital: Toward models and measures. In R. T. A. J. Leenders \& S. M. Gabby (Eds.), Corporate social capital and liability: 118-133. Boston: Kluwer Academic.

Hansen, M. T. 1999. The search-transfer problem: The role of weak ties in sharing knowledge across organization subunits. Administrative Science Quarterly, 44: 82-111.

Haunschild, P. R., \& Beckman, C. M. 1998. When do interlocks matter? Alternate sources of information and interlock influence. Administrative Science Quarterly, 43: 815-844.

Hedström, P., Sandell, R., \& Stern, C. 2000. Mesolevel networks and the diffusion of social movements: The case of the Swedish social democratic party. American Journal of Sociology, 106: 145-172.

Henisz, W. J., \& Delios, A. 2001. Uncertainty, imitation and plant location: Japanese multinational corporations, 1990-1996. Administrative Science Quarterly, 46: 443-475.

Higgins, M. C., \& Kram, K. E. 2001. Reconceptualizing mentoring at work: A developmental network perspective. Academy of Management Review, 26: 264-288.

Hinings, C. R., Hickson, D. J., Pennings, J. M., \& Schneck. R. E. 1974. Structural conditions of intraorganizational power. Administrative Science Quarterly. 19. $22-44$.

Human, S. E., \& Provan, K. G. 2000. Legitimacy building in the evolution of small-firm multilateral networks: A comparative study of success and demise. Administrative Science Quarterly, 45: 327-365.

Homans, G. C. 1950. The human group. New York: Harcourt.

Ibarra, H. 1992. Homophily and differential returns: Sex differences in network structure and access in an advertising firm. Administrative Science Quarterly, 37: $422-447$.

Ibarra, H. 1993. Personal networks of women and minorities in management: A conceptual framework. Academy of Management Review, 18: 56-87.

Ibarra, H., \& Andrews, S. B. 1993. Power, social influence 
and sense-making: Effects of network centrality and proximity on employee perceptions. Administrative Science Quarterly, 38, 277-303.

Ingram, P., \& Roberts, P. W. 2001. Friendships among competitors in the Sydney hotel industry. American Journal of Sociology, 106: 387-423.

Jablin, F. M., \& Krone, K. J. 1987. Organizational assimilation. In C. Berger \& S. H. Chaffee (Eds.), Handbook of communication science: 711-746. Newbury Park, CA: Sage.

Jaffe, A. B., \& Adams, J. D. 1996. Bounding the effects of R\&D: An investigation using matched establishmentfirm data. RAND Journal of Economics, 27: 700721.

Kanter, R. M. 1977. Men and women of the corporation. New York: Basic Books.

Keister, L. A. 1998. Engineering growth: Business group structure and firm performance in China's transition economy. American Journal of Sociology, 104: $404-440$.

Keister, L. A. 2000. Chinese business groups: The structure and impact of interfirm relations during economic development. New York: Oxford University Press.

Keister, L. A. 2001. Exchange structures in transition: Lending and trade relations in Chinese business groups. American Sociological Review, 66: 336360.

Kilduff, M. 1990. The interpersonal structure of decision making: A social comparison approach to organizational choice. Organizational Behavior and Human Decision Processes, 47: 270-288.

Kilduff, M. 1992. The friendship network as a decisionmaking resource: Dispositional moderators of social influences on organizational choice. Journal of Personality and Social Psychology, 62: 168-180.

Kilduff, M., \& Krackhardt, D. 1994. Bringing the individual back in: A structural analysis of the internal market for reputation in organizations. Academy of Management Journal, 37: 87-108.

Kilduff, M., \& Tsai, W. 2003. Social networks and organizations. Thousand Oaks, CA: Sage.

Klein, K. J., Lim, B.-C., Saltz, J. L., \& Mayer, D. M. 2004. How do they get there? An examination of the antecedents of centrality in team networks. Academy of Management Journal, 47: 952-963.

Knoke, D. 2001. Networks and organizations. In J. R. Blau (Ed.), The Blackwell companion to sociology: 327341. Malden, MA: Blackwell.

Kogut, B. 2000. The network as knowledge: Generative rules and the emergence of structure. Strategic Management Journal, 21: 405-425.

Kogut, B., \& Walker, G. 2001. The small world of Germany and the durability of national networks. American Sociological Review, 66: 317-335.
Krackhardt, D. 1990. Assessing the political landscapeStructure, cognition, and power in organizations. Administrative Science Quarterly, 35: 342-369.

Krackhardt, D. 1992. The strength of strong ties: The importance of Philos. In N. Nohria \& R. Eccles (Eds.), Networks and organizations: Structure, form, and action: 216-239. Boston: Harvard Business School Press.

Krackhardt, D., \& Porter, L. W. 1985. When friends leave: A structural analysis of the relationship between turnover and stayers' attitudes. Administrative Science Quarterly, 30: 242-261.

Krackhardt, D., \& Porter, L. W. 1986. The snowball effect: Turnover embedded in communication networks. Journal of Applied Psychology, 71: 50-55.

Krackhardt, D., \& Stern, R. 1988. Informal networks and organizational crises - An experimental simulation. Social Psychology Quarterly, 51: 123-140.

Labianca, G., \& Brass, D. J. 2004. Exploring the social ledger: Negative relationships and negative asymmetry in social networks in organizations. Academy of Management Review: In press.

Labianca, G., Brass, D. J., \& Gray, B. 1998. Social networks and perceptions of intergroup conflict: The role of negative relationships and third parties. Academy of Management Journal, 41: 55-67.

Larson, A. 1992. Network dyads in entrepreneurial settings: A study of the governance of exchange relationships. Administrative Science Quarterly, 37: 76-103.

Laumann. E. O. 1966. Prestige and association in an urban community: An analysis of an urban stratification system. New York: Bobbs-Merrill.

Laumann, E. O., \& Pappi, F. U. 1976. Networks of collective action: A perspective on community influence systems. New York: Academic Press.

Lazerfield, P. F., \& Merton, R. K. 1954. Friendship as social process: A substantive and methodological analysis. In M. Berger, T. Able, \& C. Page (Eds.), Freedom and control in modern society: 18-66. New York: Octagon.

Lee, C., Lee, K., \& Pennings, J. M. 2001. Internal capabilities, external networks, and performance: A study of technology-based ventures. Strategic Management Journal, 22: 615-640.

Levinthal, D. A., \& Fichman, M. 1988. Dynamics of interorganizational attachments: Auditor-client relationships. Administrative Science Quarterly, 33: 345-369.

Levitt, B., \& March, J. G. 1988. Organizational learning. In W. R. Scott \& J. Blake (Eds.), Annual review of sociology: 319-340. Palo Alto, CA: Annual Reviews.

Lin, N., Ensel, W. M., \& Vaughn, J. C. 1981. Social resources and strength of ties: Structural factors in occupational status attainment. American Sociological Review, 46: 393-405 
Lincoln, J. R., \& Miller, J. 1979. Work and friendship ties in organizations: A comparative analysis of relational networks. Administrative Science Quarterly, 24: 181-199.

Lincoln, J. R., Gerlach, M. L., \& Ahmadjian, C. L. 1996. Keiretsu networks and corporate performance in Japan. American Sociological Review, 61: 67-88.

Lütz, S. 1997. Learning through intermediaries: The case of inter-firm research collaborations. In M. Ebers (Ed.), The formation of inter-organizational networks: 220-237. New York: Oxford University Press.

Madhavan, R., Gnyawali, D. R., \& He, J. 2004. Two's company, three's a crowd? Triads in cooperativecompetitive networks. Academy of Management Journal, 47: 918-927.

Madhavan, R., Koka, B. R., \& Prescott, J. E. 1998. Networks in transition: How industry events (re)shape interfirm relationships. Strategic Management Journal, 19: 439-459.

Marquis, C. 2003. The pressure of the past: Network imprinting in intercorporate communities. Administrative Science Quarterly, 48: 655-689.

Marsden, P. V., \& Hurlbert, J. S. 1988. Social resources and mobility outcomes: A replication and extension. Social Forces, 66: 1038-1059.

McDonald, M. L., \& Westphal, J. D. 2003. Getting by with the advice of their friends: CEOs' advice networks and firms' strategic responses to poor performance. Administrative Science Quarterly, 48: 1-32.

McEvily, B., \& Zaheer, A. 1999. Bridging ties: A source of firm heterogeneity in competitive capabilities. Strategic Management Journal, 20: 1133-1156.

McPherson, J. M. 1983. An ecology of affiliation. American Sociological Review, 48: 519-535.

McPherson, J. M., Popielarz, P. A., \& Drobnic, S. 1992. Social networks and organizational dynamics. American Sociological Review, 57: 153-170.

McPherson, J. M., \& Smith-Lovin, L. 1987. Homophily in voluntary organizations: Status distance and the composition of face-to-face groups. American Journal of Sociology, 52: 370-379.

McPherson, J. M., Smith-Lovin, L., \& Cook, J. M. 2001. Birds of a feather: Homophily in social networks. In J. Hagan \& K. S. Cook (Eds.), Annual review of sociology, vol. 27: 415-444. Palo Alto, CA: Annual Reviews.

Mehra, A., Dixon, A. L., Brass, D. J., \& Robertson, B. 2003. The social networks of leaders: Implications for group performance and leader reputation. Paper presented at the annual meeting of the Academy of Management, Seattle.

Mehra, A., Kilduff, M., \& Brass, D. J. 1998. At the margins: A distinctiveness approach to the social identity and social networks of underrepresented groups. Academy of Management Journal, 41: 441-452.
Mehra, A., Kilduff, M., \& Brass, D. J. 2001. The social networks of high and low self-monitors: Implications for workplace performance. Administrative Science Quarterly, 46: 121-146.

Miner, A. S., Amburgey, T. L., \& Stearns, T. M. 1990. Interorganizational linkages and population dynamics: Buffering and transformational shields. Administrative Science Quarterly, 35: 689-713.

Mizruchi, M. 1996. What do interlocks do? An analysis, critique, and assessment of research on interlocking directorates. In J. Hagan \& K. S. Cook (Eds.), Annual review of sociology, vol. 22: 271-298. Palo Alto, CA: Annual Reviews.

Mizruchi, M., \& Galaskiewicz, J. 1993. Networks of interorganizational relations. Sociological Methods and Research, 22: 46-70.

Monge, P. R., \& Eisenberg, E. M. 1987. Emergent communication networks. In F. M. Jablin, L. L. Putnam, K. H. Roberts, \& L. W. Porter (Eds.), Handbook of organizational communication: An interdisciplinary perspective: 304-342. Newbury Park, CA: Sage.

Morrison, E. W. 2002. Newcomers' relationships: The role of social network ties during socialization. Academy of Management Journal, 45: 1149-1160.

Nelson, R. E. 1989. The strength of strong ties: Social networks and intergroup conflict in organizations. Academy of Management Journal, 32: 377-401.

Nohria, N., \& Ghoshal, S. 1997. The differentiated network: A new model for organizing multinational corporations. San Francisco: Jossey-Bass.

Oh, H., Chung, M., \& Labianca, G. 2004. Group social capital and group effectiveness: The role of informal socializing ties. Academy of Management Journal, 47: $860-875$.

Oliver, C. 1988. The collective strategy framework: An application to competing predictions of isomorphism. Administrative Science Quarterly, 33, 543561.

Oliver, C. 1990. Determinants of interorganizational relations: Integration and future directions. Academy of Management Review, 15: 241-265.

Ostrom, E. 1990. Governing the commons: The evolution of institutions for collective action. New York: Cambridge University Press.

Ostrom, E. 1998. A behavioral approach to the rational choice theory of collective action. American Political Science Review, 92: 1-22.

Owen-Smith, J., \& Powell, W. W. 2004. Knowledge networks as channels and conduits: The effects of spillovers in the Boston biotechnology community. Organization Science, 15: 5-21.

Palmer, D. 1983. Broken ties: Interlocking directorates and intercorporate coordination. Administration Science Quarterly, 28: 40-55. 
Palmer, D., Jennings, P. D., \& Zhou, X. 1993. Late adoption of the multidivisional form by large U. S. corporations: Institutional, political, and economic accounts. Administrative Science Quarterly, 38: 100131.

Papa, M. J. 1990. Communication network patterns and employee performance with a new technology. Communication Research, 17: 344-368.

Park, S. H., \& Ungson, G. R. 1997. The effect of national culture, organizational complementarity, and economic motivation on joint venture dissolution. Academy of Management Journal, 40: 279-307.

Pastor, J-C, Meindl, J. R., \& Mayo, M. C. 2002. A networks effects model of charisma attributions. Academy of Management Journal, 45: 410-420.

Pearce, J. A., \& David, F. R. 1983. A social network approach to organizational design-performance. Academy of Management Review, 8: 436-444.

Perry-Smith, J. E., \& Shalley, C. E. 2003. The social side of creativity: A static and dynamic social network perspective. Academy of Management Review, 28: 89-106.

Podolny, J. M. 1993. A status-based model of market competition. American Journal of Sociology, 98: $829-872$.

Podolny, J. M. 1994. Market uncertainty and the social character of economic exchange. Administrative Science Quarterly, 39: 458-483.

Polodny, J. M., \& Baron, J. N. 1997. Relationships and resources: Social networks and mobility in the workplace. American Sociological Review, 62: 673-693.

Podolny, J. M., \& Page, K. L. 1998. Network forms of organization. In J. Hagan \& K. S. Cook (Eds.), Annual review of sociology, vol. 24: 57-76. Palo Alto, CA: Annual Reviews.

Powell, W.W. 1990. Neither market nor hierarchy: Network forms of organization. In B. M. Staw \& L. L. Cummings (Eds.), Research in organizational behavior, vol. 12: 295-336. Greenwich, CT: Annual Reviews.

Powell, W.W., Koput, K., \& Smith-Doerr, L. 1996. Interorganizational collaboration and the locus of innovation: Networks of learning in biotechnology. Administrative Science Quarterly, 41: 116-145.

Powell, W.W., White, D. R., Koput, K.W., \& Owen-Smith, J. In press. Network dynamics and field evolution: The growth of interorganizational collaboration in the life sciences. American Journal of Sociology.

Provan, K., \& Milward, H. B. 1995. A preliminary theory of interorganizational network effectiveness: A comparative study of four community mental health systems. Administrative Science Quarterly, 40: 1-33.

Putnam, R. 1993. Making democracy work: Civic traditions in modern Italy. Princeton, NJ: Princeton University Press.
Raab, J., \& Milward, H. B. 2003. Dark networks as problems. Journal of Public Administration Research and Theory, 13: 413-439.

Rao, H., Davis, G. F., \& Ward, A. 2000. Embeddedness, social identity and mobility: Why firms leave NASDAQ and join the New York Stock Exchange. Administrative Science Quarterly, 45: 268-292.

Reagans, R., \& Zuckerman, E. W. 2001. Networks, diversity, and productivity: The social capital of corporate R\&D teams. Organization Science, 12: 502-517.

Reagans, R., Zuckerman, E. W., \& McEvily, B. 2004. How to make the team: Social networks vs. demography as criteria for designing effective teams. Administrative Science Quarterly: In press.

Rice, R. E., \& Aydin, C. 1991. Attitudes toward new organizational technology: Network proximity as a mechanism for social information processing. Administrative Science Quarterly, 36: 219-244.

Ring, P. S., \& Van de Ven, A. H. 1992. Structuring cooperative relationships between organizations. Strategic Management Journal, 13: 483-98.

Roberts, K. H., \& O’Reilly, C. A., III. 1979. Some correlates of communication roles in organizations. Academy of Management Journal, 22: 42-57.

Rosenkopf, L, Metiu, A, \& George V. P. 2001. From the bottom up? Technical committee activity and alliance formation. Administrative Science Quarterly, 46: $748-772$.

Rousseau, D. M., Sitkin, S. B., Burt, R. S., \& Camerer, C. 1998. Not so different after all: A cross-discipline view of trust. Academy of Management Review, 23: 393-404.

Rowley, T. J., Baum, J. A. C., Shipilov, A. V., Greve, H. R., \& Rao, H. 2004. Competing in groups. Managerial and Decision Economics, 25: In press.

Rowley, T. J., Behrens, D., \& Krackhardt, D. 2000. Redundant governance structures: An analysis of structural and relational embeddedness in the steel and semiconductor industries. Strategic Management Journal, 21: 369-386.

Rowley, T. J., Greve, H. R., Rao, H., Baum, J. A. C., \& Shipilov, A. V. In press. Time to break up: The social and instrumental antecedents of exit from interfirm exchange cliques. Academy of Management Journal.

Ruef, M. 2002. Strong ties, weak ties and islands: Structural and cultural predictors of organizational innovation. Industrial and Corporate Change, 11: 427449.

Saxenian, A. 1994. Regional advantage: Culture and competition in Silicon Valley and Route 128. Cambridge, MA: Harvard University Press.

Schermerhorn, J. R. 1977. Information sharing as an interorganizational activity. Academy of Management Journal, 20, 148-153. 
Schilling, M. A., \& Phelps, C. C. 2004. Interfirm collaboration networks: The impact of small world connectivity on firm innovation (Working paper, New York University). http://ssrn.com/abstract $=564422$.

Schulz, M. 2001. The uncertain relevance of newness: Organizational learning and knowledge flows. Academy of Management Journal, 44: 661-681.

Scott, J. 1987. Intercorporate structures in Western Europe: A comparative historical analysis. In M. Mizruchi \& M. Schwartz (Eds.), Intercorporate relations: The structural analysis of business: 208-232. New York: Cambridge University Press.

Seabright, M. A., Levinthal, D. A., \& Fichman, M. 1992. Role of individual attachments in the dissolution of interorganizational relationships. Academy of Management Journal, 35: 122-160.

Seibert, S. E., Kraimer, M. L., \& Liden, R. C. 2001. A social capital theory of career success. Academy of Management Journal, 44: 219-237.

Seidel, M-D. L., Polzer, J. T., \& Stewart, K. J. 2000. Friends in high places: The effects of social networks on discrimination in salary negotiations. Administrative Science Quarterly, 45: 1-24.

Settoon, R. P., \& Mossholder, K. W. 2002. Relationship quality and relationship context as antecedents of person- and task-focused interpersonal citizenship behavior. Journal of Applied Psychology, 87: 255267.

Shah, P. 2000. Network destruction: The structural implications of downsizing. Academy of Management Journal, 43:101-112.

Shan, W., Walker, G., \& Kogut, B. 1994. Interfirm cooperation and startup innovation in the biotechnology industry. Strategic Management Journal, 15: 387394.

Shaw, M. E. 1964. Communication networks. In L. Berkowitz (Ed.), Advances in experimental social psychology, vol. 1: 111-147. New York: Academic Press.

Sherman, J. D., Smith, H. L., \& Mansfield, E. R. 1986. The impact of emergent network structure on organizational socialization. Journal of Applied Behavioral Science, 22: 53-63.

Shrader, C. B., Lincoln, J. R., \& Hoffman, A. N. 1989. The network structures of organizations: Effects of task contingencies and distributional form. Human Relations, 42: 43-66.

Silverman, B. S., \& Baum, J. A. C. 2002. Alliance-based competitive dynamics. Academy of Management Journal, 45: 791-806.

Singh, J. V., Tucker, D. J., and Meinhard, A. G. 1991. Institutional change and ecological dynamics. In W. W. Powell \& P. J. DiMaggio (Eds.), The new institutionalism in organizational analysis: 390422. Chicago: University of Chicago Press.

Soda, G., Usai, A. \& Zaheer, A. 2004. Network memory:
The influence of past and current networks on performance. Academy of Management Journal. 47: 893-906.

Soh, P., Mahoom, I., Mitchell, W. 2004. Dynamic inducements in R\&D investment: Market signals and network locations. Academy of Management Journal, 47: 907-917.

Soule, S. A. 1997. The student divestment movement in the United States and tactical diffusion: The shantytown protest. Social Forces, 75: 855-883.

Sparrowe, R. T., \& Liden, R. C. 1997. Process and structure in leader-member exchange. Academy of Management Review, 22: 522-552.

Sparrowe, R. T., Liden, R. C., Wayne, S. J., \& Kraimer, M. L. 2001. Social networks and the performance of individuals and groups. Academy of Management Journal, 44: 316-325.

Stinchcombe, A. L. 1965. Social structure and organizations. In J. G. March (Ed.), Handbook of organizations: 142-193. Chicago: Rand McNally.

Stuart, T. E. 1998. Network positions and propensities to collaborate: An investigation of strategic alliance formation in a high-technology industry. Administrative Science Quarterly, 43: 668-698.

Stuart, T. E., Hoang, H., \& Hybels, R. C. 1999. Interorganizational endorsements and the performance of entrepreneurial ventures. Administrative Science Quarterly, 44: 215-452.

Tichy, N. M., \& Fombrun, C. 1979. Network analysis in organizational settings. Human Relations, 32: 923965.

Tsai, W. 2000. Social capital, strategic relatedness, and the formation of intra-organizational linkages. Strategic Management Journal, 21: 925-939.

Tsai, W. 2001. Knowledge transfer in intraorganizational networks: Effects of network position and absorptive capacity on business-unit innovation and performance. Academy of Management Journal, 44: 9961004.

Tsai, W. 2002. Social structure of "coopetition” within a multiunit organization: Coordination, competition, and intraorganizational knowledge sharing. Organization Science, 13: 179-190.

Tsai, W., \& Ghoshal, S. 1998. Social capital and value creation: The role of intrafirm networks. Academy of Management Journal, 41: 464-476.

Tsui, A. E., \& O’Reilly, C. A.. 1989. Beyond simple demographic effects: The importance of relational demography in superior-subordinate dyads. Academy of Management Journal, 32: 402-423.

Umphress, E. E., Labianca, G., Brass D. J., Kass, E., \& Scholten, L. 2003. The role of instrumental and expressive social ties in employees' perceptions of organizational justice. Organization Science, 14: $738-753$. 
Uzzi, B. 1996. The sources and consequences of embeddedness for the economic performance of organizations: The network effect. American Sociological Review, 61: 674-698.

Uzzi, B. 1997. Social structure and competition in interfirm networks: The paradox of embeddedness. Administrative Science Quarterly, 42: 35-67.

Uzzi, B., \& Spiro, J. 2004. Small worlds and big differences in success. Working paper, Northwestern University, Evanston, IL.

Venkatraman, N., \& Lee, C. 2004. Preferential linkage and network evolution: A conceptual model and empirical test in the U.S. video game sector. Academy of Management Journal, 47: 876-892.

Wagner, G. W., Pfeffer, J., \& O’Reilly, C. A., III. 1984. Organizational demography and turnover in topmanagement groups. Administrative Science Quarterly, 29: 74-92.

Walker, G. 1985. Network position and cognition in a computer software firm. Administrative Science Quarterly, 30: 103-130.

Wasserman, S., \& Faust, K. 1994. Social network analysis: Methods and applications. Cambridge, England: Cambridge University Press.

Watts, D. J. 1999. Networks, dynamics, and the smallworld phenomenon. American Journal of Sociology, 105:493-527.

Watts, D. J., \& Strogatz, S. H. 1998. Collective dynamics of "small-world” networks. Nature, 393: 440-442.

Wegener, B. 1991. Job mobility and social ties: Social resources, prior job, and status attainment. American Sociological Review, 56: 60-71.

Wellman, B. 1992. Which types of ties and networks provide what kinds of social support? In E. J. Lawler (Ed.), Advances in group processes, vol. 9: 207-235. Greenwich, CT: JAI Press.

Westphal, J. D., Seidel, M. D., \& Stewart, K. J. 2001. Second-order imitation: Uncovering latent effects of board network ties. Administrative Science Quarterly, 46: 717-747.

Westphal, J. D., \& Zajac, E. J. 1997. Defections from the inner circle: Social exchange, reciprocity, and the diffusion of board independence in U.S. corporations. Administrative Science Quarterly, 42: 161183.

White, H. C. 2001. Markets from networks: Socioeco- nomic models of production. Princeton, NJ: Princeton University Press.

White, H. C., Boorman, S., \& Breiger, R. 1976. Social structure from multiple networks, I: Blockmodels of roles and positions. American Journal of Sociology, 81: $730-80$.

Williamson, O. 1975. Markets and hierarchies: Analysis and antitrust implications. New York: Free Press.

Wood, D. J., \& Gray, B. 1991. Toward a comprehensive theory of collaboration. Journal of Applied Behavioral Science, 27: 139-162

Yli-Renko, H., Autio, E., \& Sapienza, H. J. 2001. Social capital, knowledge acquisition, and knowledge exploitation in young technology-based firms. Strategic Management Journal, 22: 587-613.

Zaheer, A., McEvily, B., \& Perrone, V. 1998. Does trust matter? Exploring the effects of interorganizational and interpersonal trust on performance. Organization Science, 9: 141-59.

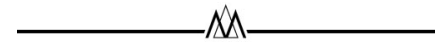

Daniel J. Brass (dbrass@uky.edu) is the J. Henning Hilliard Professor of Innovation Management at the University of Kentucky. He received his Ph.D. in business administration from the University of Illinois at UrbanaChampaign. His research focuses on the antecedents and consequences of social networks in organizations.

Joseph Galaskiewicz (galaskie@email.arizona.edu) is a professor of sociology at the University of Arizona, Tuscon. He received his Ph.D. in sociology from the University of Chicago. His research focuses on interorganizational networks of corporations and nonprofit organizations.

Henrich R. Greve (henrich.greve@bi.no) is a professor of strategy at the Norwegian School of Management BI. He received his Ph.D. in business from Stanford University. His research examines the effect of interorganizational networks on competitive strategies and innovations.

Wenpin Tsai (wtsai@psu.edu) is an assistant professor of management at the Pennsylvania State University. He received his $\mathrm{Ph} . \mathrm{D}$. in strategic and international management at the London Business School. His current research focuses on social capital, organizational knowledge, and the evolution of strategic networks. 